\title{
Design of Stand-Alone Proton Exchange Membrane Fuel Cell Hybrid System under Amman Climate
}

\author{
Wala' Nsour r*, Tamara Taa'mneh'1, Osama Ayadi', Jamil Al Asfar' \\ 1 Mechanical Engineering Department, The University of Jordan, Amman 11942, Jordan \\ * Corresponding author's e-mail:w.nsour90@yahoo.com
}

\begin{abstract}
Renewable energy application is gaining a wide acceptance by end users; however, considering the fact that renewable energy is intermittent, variable and cannot be predicted, the need of storage systems is becoming a necessity at both micro and macro levels. Fuel cell technology is one of the most promising storage systems due to the fact that hydrogen has high energy density. This paper presents a design of stand-alone PV-PEMFC hybrid system for a small house under Amman climate. The simulation results show that the optimal size of PV array, fuel cell (PEMFC), inverter, electrolyzer (ELE) and $\mathrm{H}_{2}$ Tank capacity were $10 \mathrm{~kW}, 1 \mathrm{~kW}, 5 \mathrm{~kW}, 6 \mathrm{~kW}$, and $5 \mathrm{~kg}$ respectively. Hydrogen proved itself as a low carbon energy source, which is environmental friendly and characterized with high energy content per unit mass. Due to fuel cells technology, hydrogen can be used for inter-season storage.
\end{abstract}

Keywords: proton exchange membrane fuel cell (PEMFC), PV system, hydrogen storage, stand-alone, hybrid system, HOMER.

\section{INTRODUCTION}

Diminishing resources, severe environmental pollution and an ever increasing demand for energy are forcing the energy sector towards the use of Renewable Energy (RE). The RE application is gaining a wide acceptance by end users; however, considering the fact that it is intermittent, variable and cannot be predicted, the need of storage systems is becoming a necessity at both micro and macro levels.

Fuel cell technology is one of the most promising storage systems due to the fact that hydrogen has high energy density. Fuel cell basic principle is based on the simple equation:

$$
2 \mathrm{H}_{2}+\mathrm{O}_{2} \rightarrow 2 \mathrm{H}_{2} \mathrm{O}+\text { HEAT }
$$

However, electrical energy is produced instead of heat. [1]

The main six types of fuel cells: are proton exchange membrane fuel cell (PEMFC), direct methanol fuel cell (DMFC), alkaline fuel cell (AFC), phosphoric acid fuel cell (PAFC), solid oxide fuel cell (SAFC) and molten carbonate fuel cell (MCFC). PEMFC as shown in Figure 1 are the most promising technology due to the low operating temperature, fast start-up, low noise, low mass and high density [2].

The Solar-Hydrogen energy cycle shown below in Figure 2, is the conversion of solar energy to electricity which is later converted to hydrogen. Once electricity is needed, hydrogen is converted back to electricity to meet the demand. $\mathrm{H}_{2}$ is stored using many methods, such as: $\mathrm{H}_{2}$ cylinders, $\mathrm{H}_{2}$ fuel tanks, and $\mathrm{H}_{2}$ vessels.

\section{Literature review}

A solar-hydrogen system is a kind of standalone power system, which can supply low energy dwellings with energy. Many studies on such systems have been performed. A subset of literature has been selected, based on its direct relevance to the proposed system.

Ulleberg and Mørner (1997) simulated a stand-alone system using TRANSYS software, 


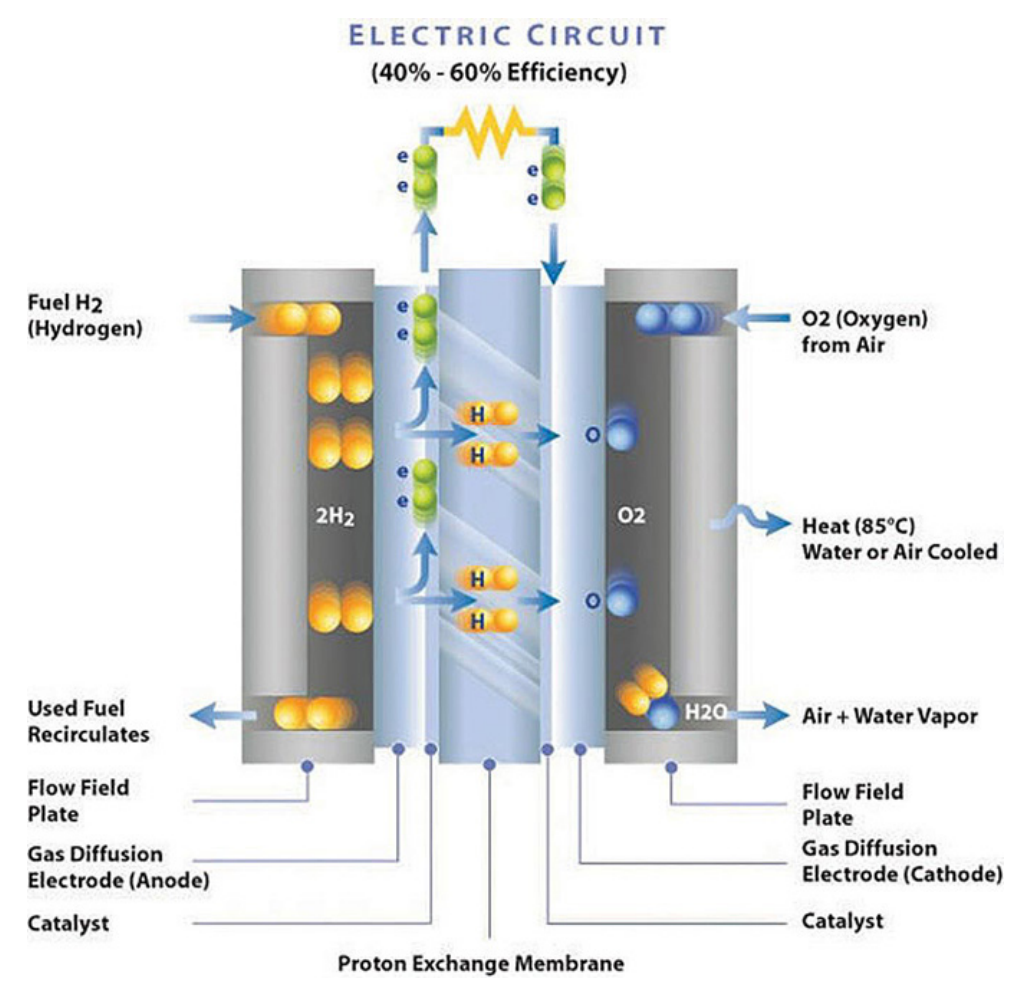

Figure 1. Basic structure of PEM fuel cell

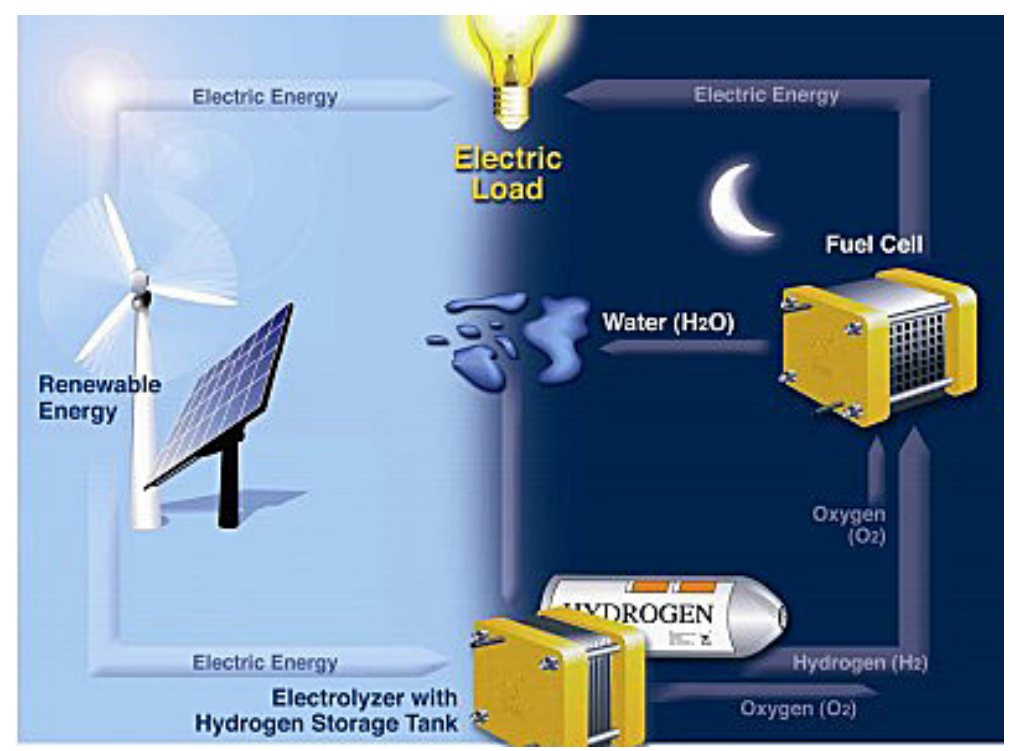

Figure 2. Solar Hydrogen energy cycle

as shown in Figure 3. It consists of a photovoltaic (PV) cell array, an electrolyzer, a hydrogen $\left(\mathrm{H}_{2}\right)$ storage, a fuel cell, a catalytic burner, a lead-acid battery, DC/DC converters, DC/AC inverters, diodes, a solar collector, and a water storage tank. The results showed that the size of the solar-hydrogen system can be significantly reduced [3].

Dou \& Andrews (2012) focused on the design of a control unit for a stand-alone solar-hydrogen system, as shown in Figure 4, with hydrogen generation via a proton exchange membrane (PEM) electrolyzer, compressed gas or metal-hydride hydrogen storage, and a PEM fuel cell [4].

Djafour et al. (2014) presented the results of sizing a system of hydrogen production obtained through an electrolyzer, powered by photovoltaic solar modules installed in Ouargla, Algeria to meet the needs of hydrogen for a fuel cell of type, PEMFC[5]. Figure 5 illustrates their model. 


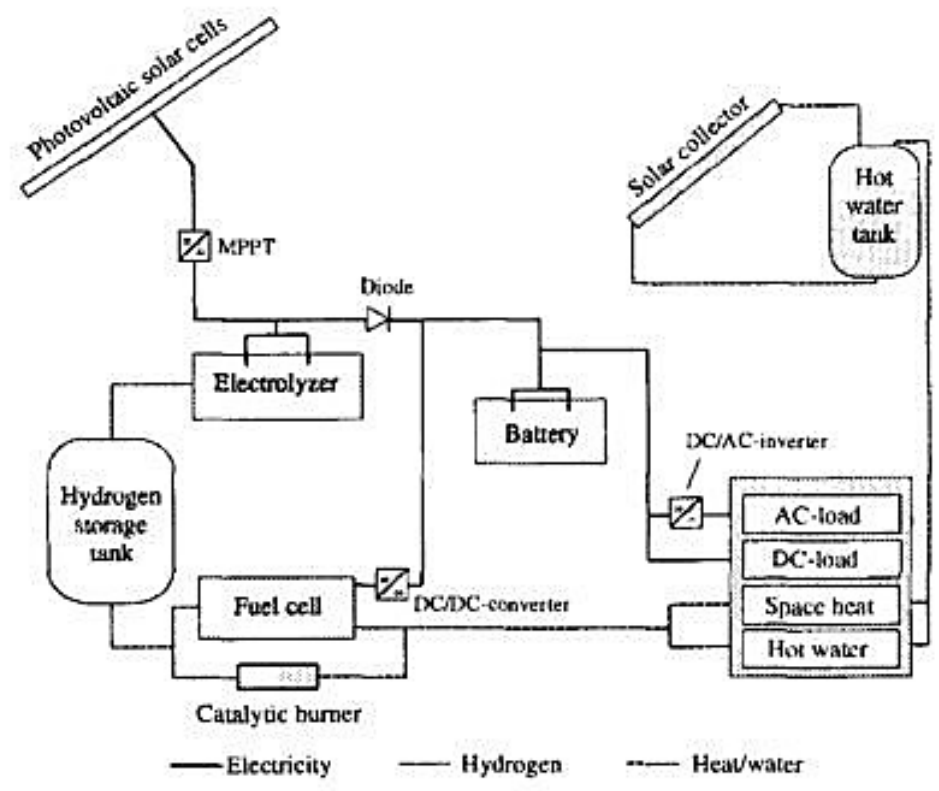

Figure 3. Schematic of the simulated solar-hydrogen system [3]

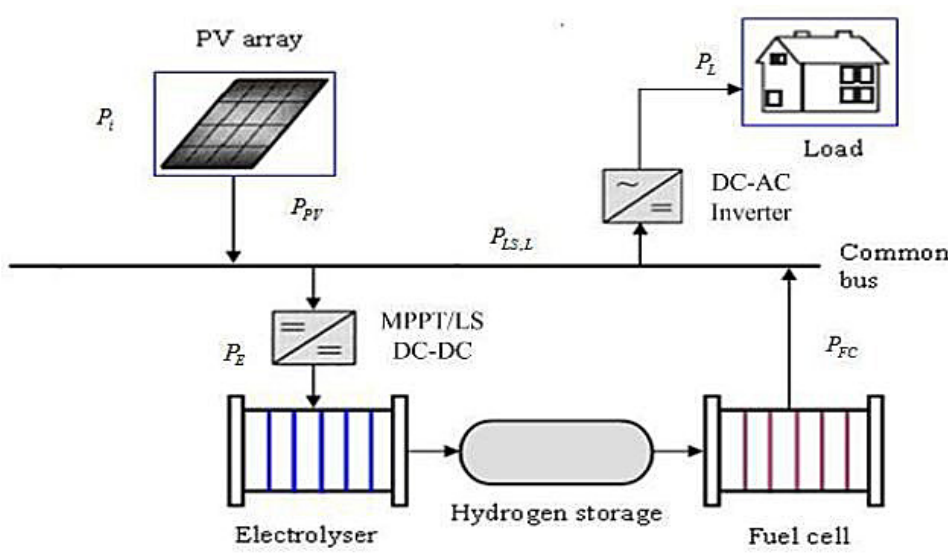

Figure 4. basic solar-hydrogen system for a Remote area power supply application Solar [4]

\section{METHODOLOGY}

An off-grid PV system with hydrogen storage was designed for a house in Amman with the following assumptions: House loads will be used all year. The load of appliances will be estimated and off-grid PV system will be sized accordingly. Hydrogen storage will be designed for two days of autonomy. The required size of the hydrogen tank will be calculated. Fuel cell will be used to convert hydrogen back to electricity when needed. For this system, an experimental model was investigated in labs to maintain the $\mathrm{I}-\mathrm{V}$ curve of fuel cell and efficiency of overall system for a small scale load. Finally, proper simulation software will be implemented to maintain more accurate outcomes for this system. This system consists of: PV panels, $\mathrm{H}_{2}$ fuel cells, electrolyzer and hydrogen storage.

\section{Experimental setup}

In this part, the system is presented in greater detail. Figure 6 below shows the setup components.

Experimental system components are:

1. Double cell PEM Electrolyzer stack

2. $80 \mathrm{~cm}^{3}$ Hydrogen storage tank

3. PEM fuel cell stack

4. Fan Tutorial

5. 13 W Solar Module

6. Lamps for lighting the solar module

7. Measuring transformer card

8. Lamp as a load

9. Power output

10. Electrical protection 
The first step is to power the two lights modules that are used to energize the photovoltaic solar module. This is alternative to using the direct sun for solar module.

The second step is to connect the output of the photovoltaic solar module to the input of the electrolyzer stack. The lamp modules need to be switched on, the water tank of the electrolyzer stack must be filled with distilled water and the output of the electrolyzer stack connected to the input of the gas storage tank. This enables the hydrogen to accumulate in the storage tank. One also needs to make sure to open the sealing cap of the fuel cell so that the gas can flow through the fuel cell.

The third step is to connect the hydrogen output of the storage tank to one of the hydrogen inputs of the fuel cell. The fan starts running owing to the electric power generated by the fuel cell stack.

The electrical energy that comes from solar PV modules combines with the water in a device known as electrolyzer. The electrolyzer generates hydrogen $\mathrm{H}_{2}$ and byproducts gas $\mathrm{O}_{2}$. $\mathrm{H}_{2}$ is stored in storage tanks for later use. When it is required again, $\mathrm{H}_{2}$ recombines with atmospheric $\mathrm{O}_{2}$ in the fuel cell to generate electricity which is fed to the final load.

After connecting all the components and when the lights turned on, while keeping the sealing cap of fuel cell closed, the electrolyzer started to split water into $\mathrm{H}_{2}$ and $\mathrm{O}_{2}$. Figure 7 shows the lab experiment. When hydrogen accumulates in the tank, the sealing cap can be opened to allow gas to flow through the fuel cell and produce electricity.

The obtained characteristics I-V curve and Power-Time curve of this fuel cell are presented in Figure 8 and Figure 9.

\section{System design}

The system design, as shown in Figure 10, compromises of the following components:

1. PV modules

2. Inverter

3. Electrolyzer

4. Hydrogen storage tank

5. PEM fuel cell

6. Water source (water tank)

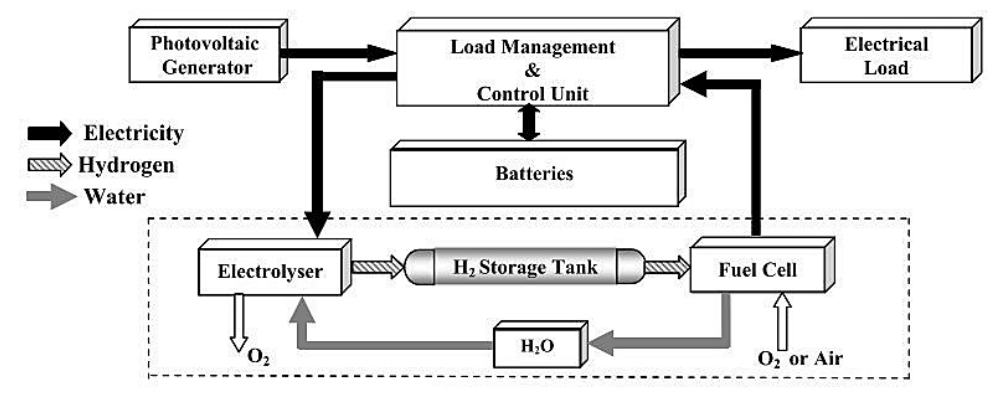

Figure 5. The hybrid system (PV-PEMFC) for energy production [5]

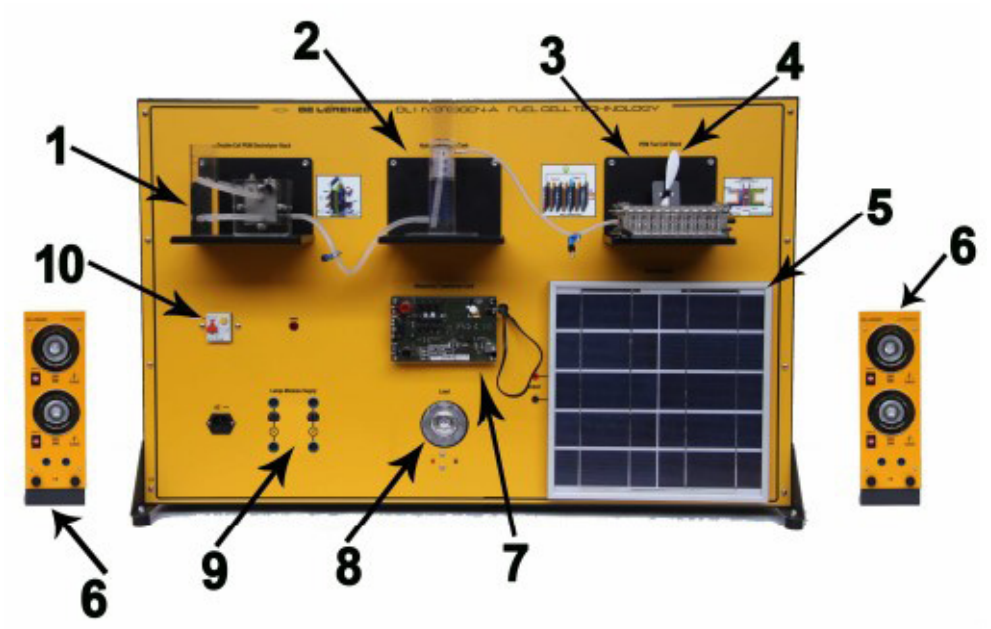

Figure 6. Experimental setup components 


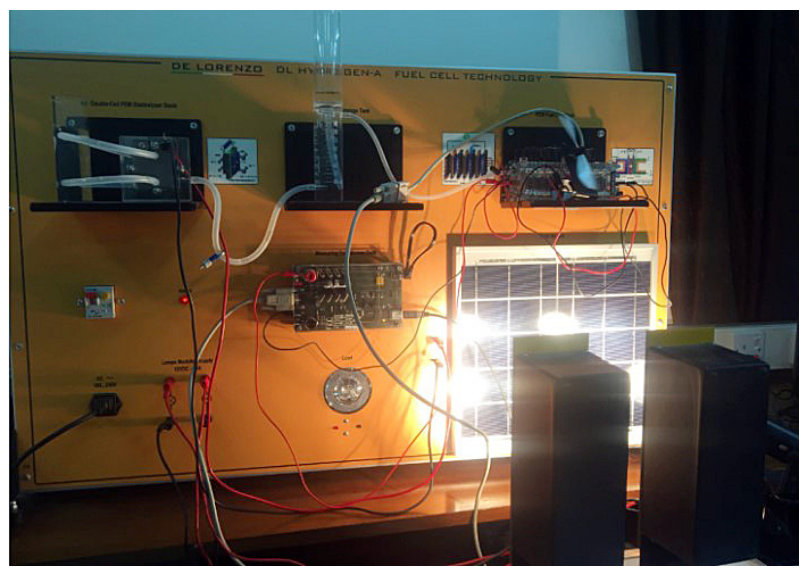

Figure 7. Lab experiment

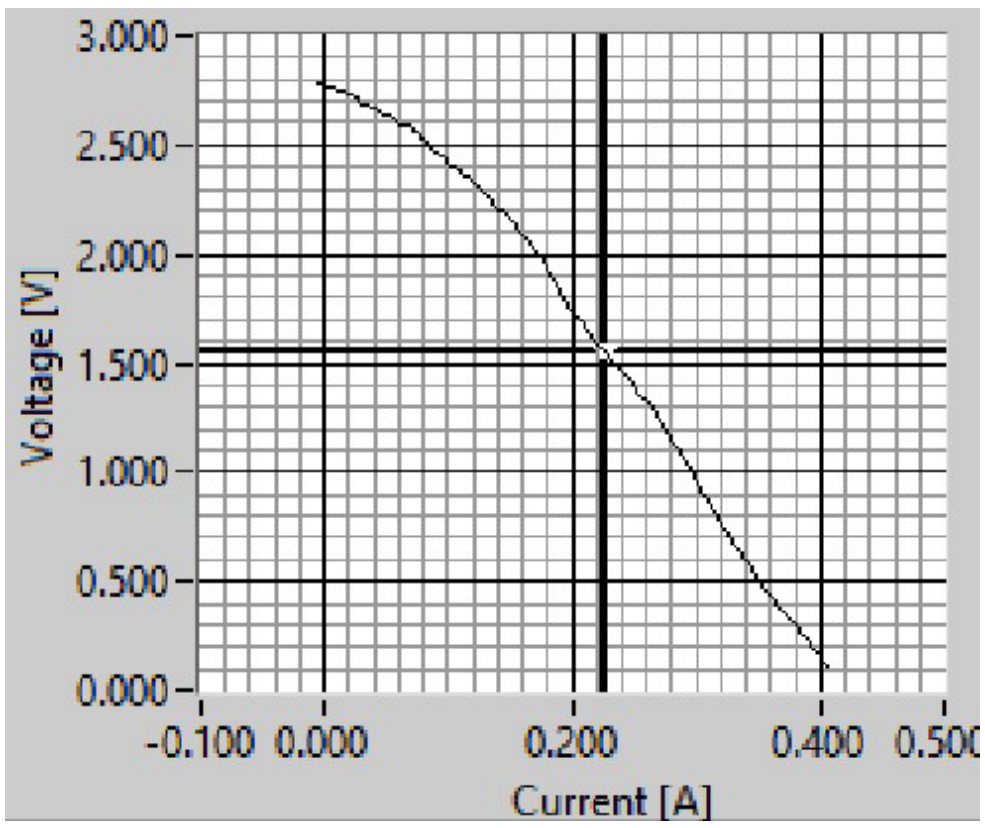

Figure 8. Characteristics I-V curve of experimental fuel cell

The system working process starts with the PV modules generating DC electricity during sun hours, this electricity is either fed directly to the electrolyzer or to the inverter. The inverter changes DC to AC to power house appliances. The excess electricity is fed to electrolyzer which uses it to split water into $\mathrm{H}_{2}$ and $\mathrm{O}_{2} . \mathrm{O}_{2}$ is ejected to ambient air while $\mathrm{H}_{2}$ is stored in the storage tanks. Later, at times of low or no sufficient solar energy to meet the load, hydrogen is drawn from storage tanks and fed into the fuel cell to produce electricity that meets the supply shortage.

The assumptions in Table 1 above were made to size the required PV system to cover the demand of small house in Amman. Monthly radiation in Amman is presented in Figure 11.

\section{Sample calculations:}

$\mathrm{Ed}=8.660 \mathrm{kWh} /$ day.

Annual irradiation $=5.62 \mathrm{kWh} / \mathrm{m}^{2} /$ day.

Efficiency of electricity system $=$

$=$ eff. of inverter $\cdot$ eff. of panel .

- eff. of electrolyzer $\cdot$ eff. of fuel cell $=$

$=0.97 \cdot 0.162 \cdot 0.79 \cdot 0.48=0.06=6 \%$

$$
\begin{gathered}
P p v=E d /(P S H \cdot \text { eff. })= \\
=8.66 /(5.62 \cdot 0.06)=25.68 \mathrm{kWh}
\end{gathered}
$$

$\mathrm{PV}$ module $=315 \mathrm{~W}$.

Number of panels $=82$. 


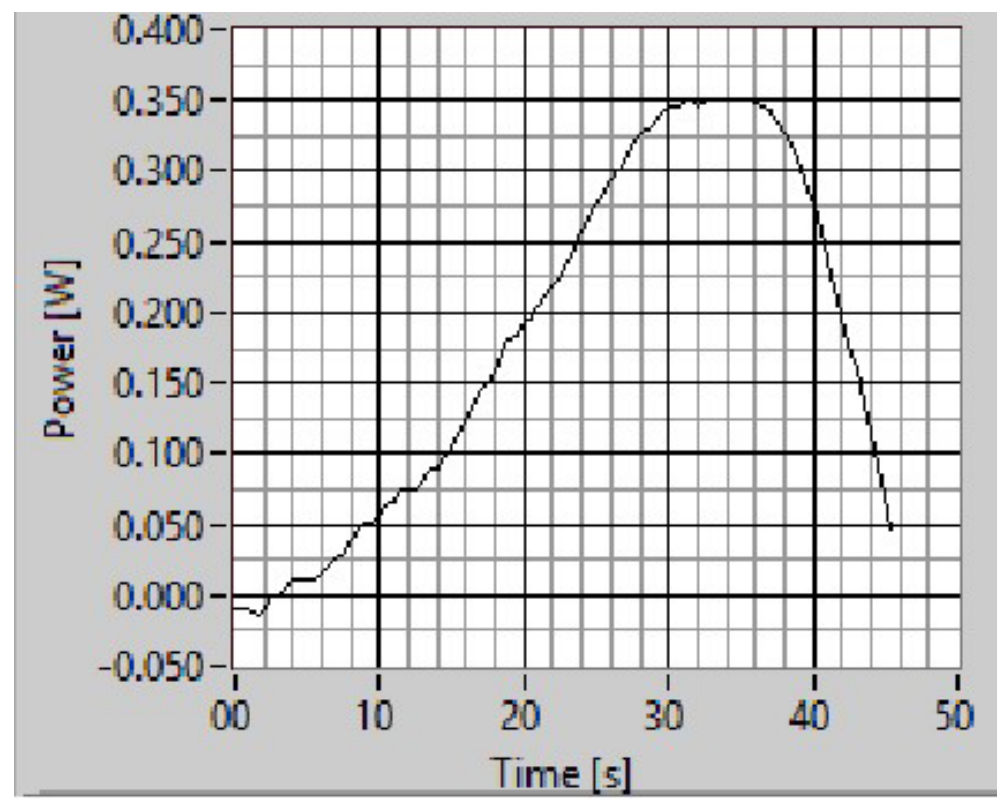

Figure 9. Power-Time curve of experimental fuel cell

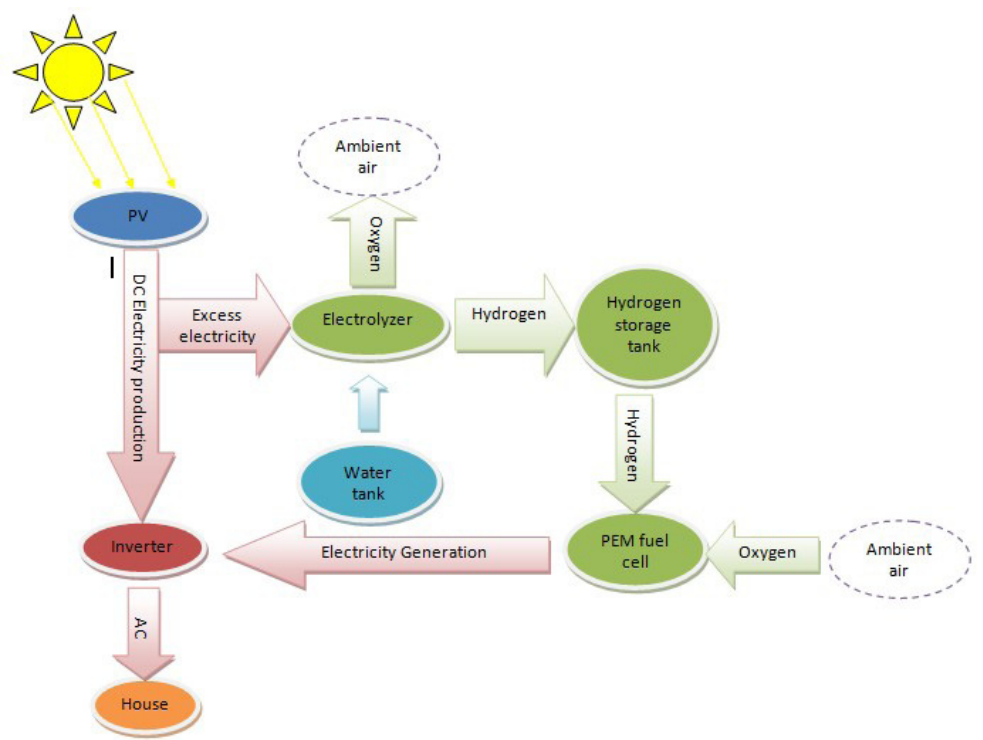

Figure 10. System process

System size $=315.90=28.35 \mathrm{kWp}$, $10 \%$ oversize.

Storage $=($ Number of days $\cdot$ Energy daily $) /$

$/$ (allowable depth of discharge $\cdot$ eff. electrolyzer $)=$

$=2 \cdot 5.620 / 1 \cdot 0.79=14.23 \mathrm{kWh}$

Experimental fuel cell storage:

- $13 \mathrm{~W}(\mathrm{PV})=80 \mathrm{~cm}^{3}$ hydrogen tank House PV system storage:

- $28350 \mathrm{~W}(\mathrm{PV})=174461.54 \mathrm{~cm}^{3}$ hydrogen tank

Storage tank needed $=0.17446154 \mathrm{~m}^{3}$ at atmospheric pressure.
On the basis of unit conversion data for hydrogen:

- $1 \mathrm{~m}^{3}$ gas $\rightarrow 0.08988 \mathrm{~kg}$

- $0.17446154 \mathrm{~m}^{3} \rightarrow 0.0156 \mathrm{~kg}$

\section{Modeling and simulation}

HOMER is a computer model that simplifies the task of designing hybrid renewable micro-grids, whether remote or attached to a larger grid. Optimization and sensitivity analysis algorithms allow to evaluate the economic and technical feasibility of a large number of 
technology options and to account for variations in technology costs and energy resource availability.

Different sizes and ranges of each component inside the system have been used in modeling and simulation the proposed problem. The figure below shows the model generated using HOMER software. This model analyzes a standalone PV-hydrogen system.

Excess solar power goes to the electrolyzer, which generates hydrogen for storage in the hydrogen tank. The fuel cell generates electricity using the hydrogen stored as fuel.

Figure 12 shows this model on HOMER.

\section{RESULTS}

After using simulations and calculations by HOMER ${ }^{\circledR}$ software, the following results were obtained; PV system is $10 \mathrm{~kW}$, PEMFC is $1 \mathrm{~kW}$ and $\mathrm{H} 2$ Storage is $5 \mathrm{~kg}$. Detailed results are shown in Figures 13, 14, 15 and 16.

\section{CONCLUSION}

Solar hydrogen system used as an energy supply is a good solution to solve the fuel logistic problem for remote, desert areas in Amman that can at least be capable of providing necessary light and power. In this study, we have showed an example of sizing of a solar generator that can make a stand-alone hybrid power generation

Table 1: House load assumptions

\begin{tabular}{|l|c|c|c|c|}
\hline \multicolumn{1}{|c|}{ Appliance } & Power & No. & $\begin{array}{c}\text { Avg hrs/ } \\
\text { day }\end{array}$ & Avg Wh/day \\
\hline Light & 11 & 20 & 4 & 880 \\
\hline TV & 60 & 2 & 5 & 600 \\
\hline Computer & 60 & 1 & 3 & 180 \\
\hline Refrigerator & 80 & 1 & 24 & 1920 \\
\hline Kettle & 1000 & 1 & 0.2 & 200 \\
\hline Microwave & 700 & 1 & 0.4 & 280 \\
\hline Food processor & 400 & 2 & 0.15 & 120 \\
\hline $\begin{array}{l}\text { Washing } \\
\text { machine }\end{array}$ & 800 & 1 & 0.6 & 480 \\
\hline A/C unit & 1000 & 2 & 2 & 4000 \\
\hline \multicolumn{5}{|l|}{ Total Wh / day } \\
\hline
\end{tabular}

Annual irradiation deficit due to shadowing (horizontal): $0.8 \%$

\begin{tabular}{|l|l|l|l|l|}
\hline Month & Hh & Hopt & $\mathrm{H}(90)$ & lopt \\
\hline Jan & 2850 & 3970 & 3690 & 54 \\
\hline Feb & 3580 & 4550 & 3670 & 46 \\
\hline Mar & 5250 & 6060 & 3970 & 35 \\
\hline Apr & 6320 & 6570 & 3110 & 20 \\
\hline May & 7470 & 7150 & 2260 & 7 \\
\hline Jun & 8380 & 7610 & 1780 & -1 \\
\hline Jul & 8150 & 7580 & 1980 & 3 \\
\hline Aug & 7510 & 7560 & 2860 & 15 \\
\hline Sep & 6390 & 7200 & 4130 & 31 \\
\hline Oct & 5000 & 6320 & 4810 & 44 \\
\hline Nov & 3580 & 5000 & 4550 & 54 \\
\hline Dec & 2790 & 4040 & 3930 & 57 \\
\hline Year & 5620 & 6140 & 3390 & 27 \\
\hline
\end{tabular}

Hh: Irradiation on horizontal plane (Wh/m2/day)

Hopt: Irradiation on optimally inclined plane (Wh/m2/day)

$H(90)$ : Irradiation on plane at angle: $90 \mathrm{deg}$. (Wh/m2/day)

lopt: Optimal inclination (deg.)

Figure 11: PVGIS monthly radiation in Amman. 
system, mainly with the production of hydrogen needed to run a PEMFC fuel cell.

Since no fuel is burned to make energy, fuel cells are fundamentally more efficient than the combustion systems. Fuel cells are considered environmental friendly, as hydrogen is a low-carbon energy source.

The advantage of using hydrogen for energy storage is that it can be stored as a compressed gas, or in metal hydrides that have a high energy per unit mass on a system basis, without the self-discharge of a battery. The simulation results showed that using a solar-hydrogen system can reduce the size of a PV system.

Due to fuel cells technology, hydrogen can be used for inter-season storage. The excess electricity production in summer can be used to cover the heating load in winter.

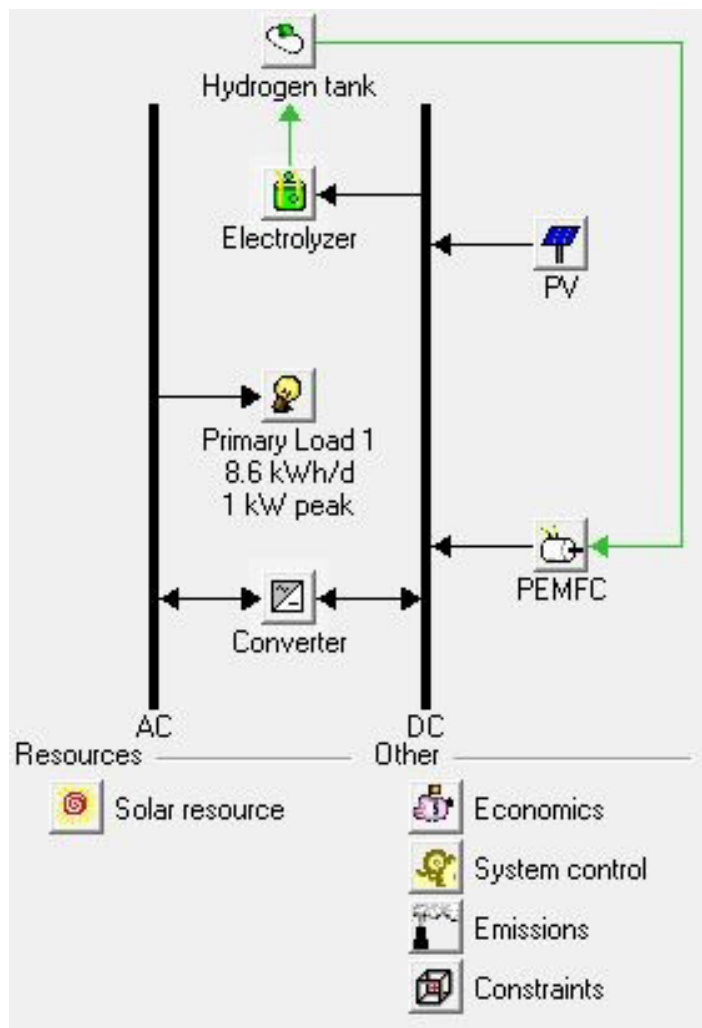

Figure 12. Stand-alone solar-hydrogen system

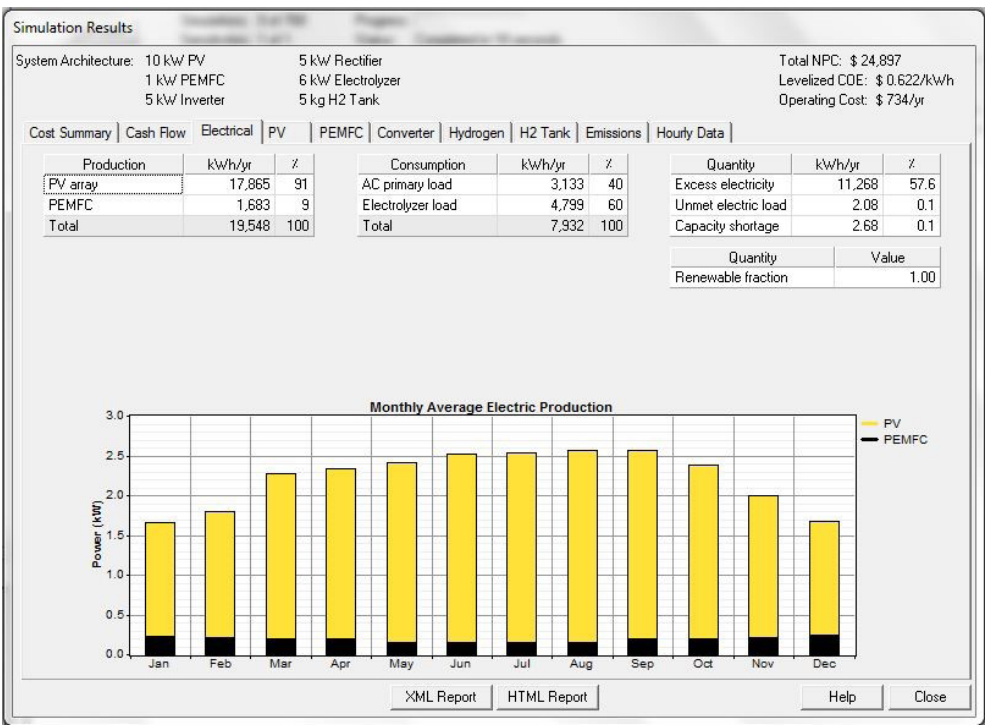

Figure 13. Monthly average electric production 


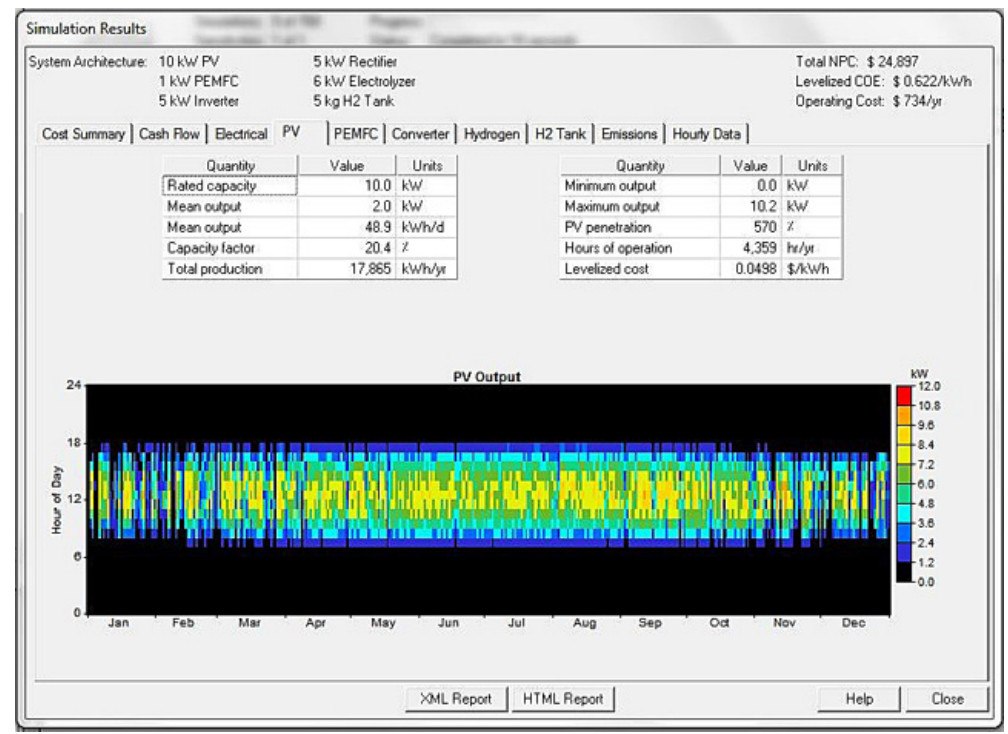

Figure 14. Monthly PV output

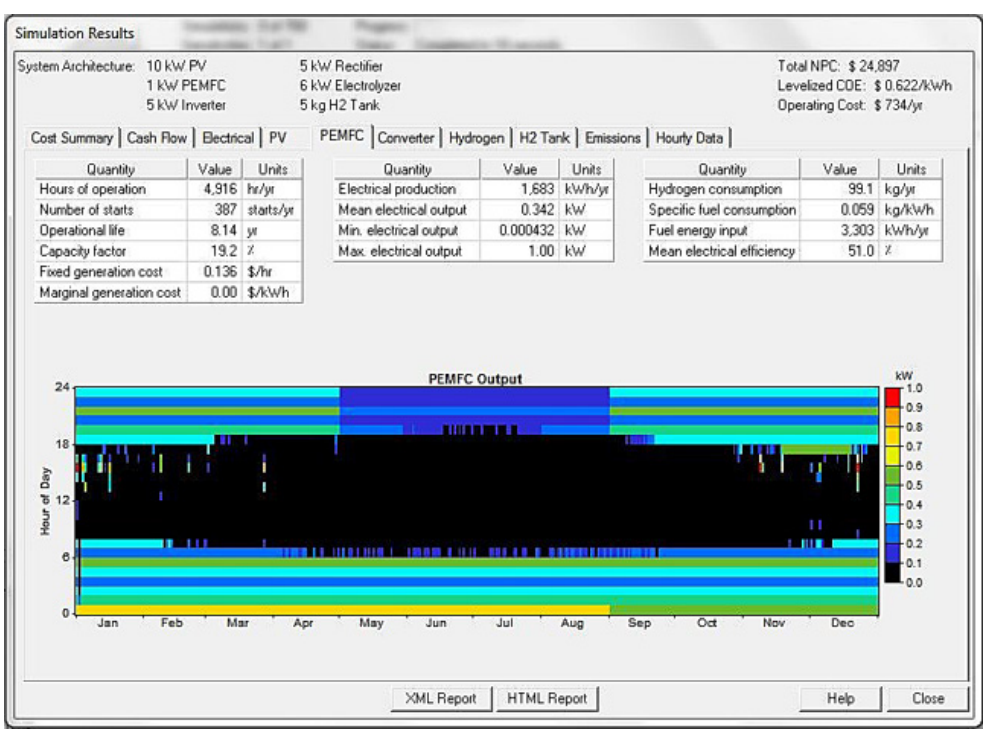

Figure 15. Monthly PEMFC output

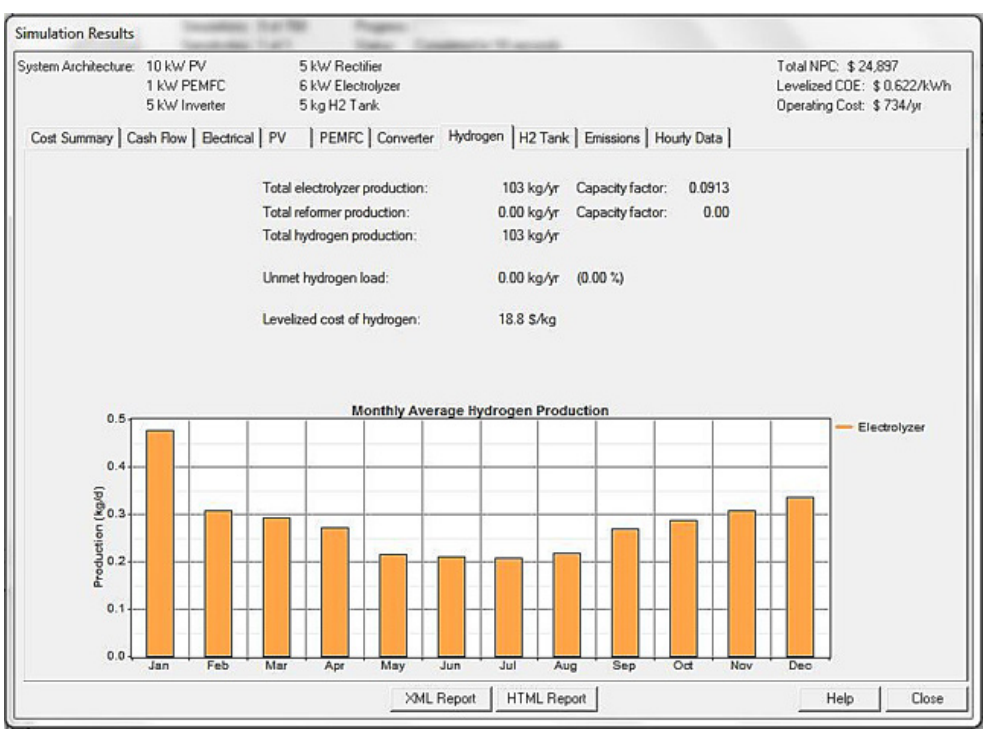

Figure 16. Monthly average $\mathrm{H} 2$ production 


\section{REFERENCES}

1. J. Larminie and A. Dicks. 2003. Fuel cell systems explained.

2. J.H. Wee. 2007. Applications of proton exchange membrane fuel cell systems, Renew. Sustain. Energy Rev., 11(8), 1720-1738.

3. Ulleberg and S.O. Mørner. 1997. TRNSYS simula- tion models for solar-hydrogen systems, Sol. Energy, 59, no. 4-6-6 pt 4, 271-279.

4. X.X. Dou and J. Andrews. 2012. Design of a dynamic control system for standalone solar-hydrogen power generation, Procedia Eng., 49, 107-115.

5. A. Djafour, M.S. Aida, and B. Azoui. 2014. Photovoltaic assisted fuel cell power systems, Energy Procedia, 50, 306-313. 